\title{
Nurturing Habits of Mind (HOM) Through Thinking Based Learning (TBL) in Doing Science Technology, Engineering and Mathematics (STEM) Project
}

\author{
Hartini Hashim ${ }^{1}$, Mohd Norawi Ali ${ }^{2}$ and Mohd Ali Samsudin² \\ ${ }^{1}$ SMK Sultan Ismail, Kota Bharu Kelantan \\ ${ }^{2}$ School of Educational Studies, Universiti Sains Malaysia \\ Corresponding author: mnorawi63@gmail.com
}

\begin{abstract}
Habits of mind (HOM) is one of the kind response to those questions and problems whereby the answers to which are not immediately known which can attribute to effective problem solvers and critical thinking development. However, the emphasis on this aspect is still low especially among science educators as well as secondary science students which in the long run will retard the production of knowledge worker who are able to behave when confronted with life's problems. The study addressed the integration of Thinking Based Learning (TBL) and the $6 \mathrm{E}$ Instructional Model as a teaching approach in nurturing habits of mind among secondary students while doing their Science, Technology, Engineering and Mathematics (STEM) project. The study involved 30 students from a Lower Secondary School in a sub urban school in Kota Bharu, Kelantan. Students were given a STEM Raft Module integrating TBL and 6E Instructional Model for five weeks to come out with a model of a raft based on science concepts using material available in their community. Data of the study were captured from students' documentation analysis, classroom observation using camera and video cam recording, and interview. The findings showed that TBL and 6E Instructional Model can nurture habits of mind among secondary students while doing their STEM project. Seven characteristics of habits of mind have been identified; (1) questioning and problem solving, (2) listening with understanding and empathy, (3) thinking about your thinking, (4) thinking flexibility, (5) applying past knowledge to novel situations, (6) creating, imagining and innovating and (7) thinking independently.
\end{abstract}

Keywords: Habits of mind, Thinking Based Learning, the 6E Instructional Model, STEM project

\section{INTRODUCTION}

STEM is an acronym for Science, Technology, Engineering and Mathematics. STEM disciplines were introduced through Secondary School Curriculum Standard (KSSM) beginning 2017 to Form One secondary school students. In this study, STEM project is the combine of project based learning and problem solving approaches. As a learning activity, it is strongly anchored in the view that education is rooted in reality, and therefore, in making and doing things, certain qualities of mind and character need cultivation [1]. The aim of this study was to give a new breath to the integration of Thinking Based Learning (TBL) and the 6E Instructional Model as a teaching approach in nurturing habits of mind. Thinking Based Learning is one of teaching approaches that compromised of three main part known as (1) skilful thinking, (2) metacognition and (3) habits of mind [2].

Habits of mind have been proposed by [3] as characteristics of how competent individuals act when they faced problems in which they had to figure out the solutions. This study posited the habits 
of mind that can be nurtured while doing STEM project. The study involved 30 students from a sub urban Lower Secondary School in Kota Bharu, Kelantan.

\section{Background of the study}

Recently, even though many researcher broadly discussed the importance of student's critical thinking skills development but the factors that attributable to it remain unstudied [4]. Habits of mind one of those factors recently discussed by academic research. In this study, habits of mind have been addressed. Habits of mind are defined as mental habits which enable students to become life-long learners whereby this mental habits include creative thinking, critical thinking and self- regulation [5]. As defined by [6] the presence of "Habits of mind" meant having a disposition towards behaving intelligently when confronted with problems.

In this study, the $6 \mathrm{E}$ Instructional Model has been used as a teaching method. (1) Engage, (2) Explore, (3) Explain, (4) Engineering, (5) Enrich and (6) Evaluate are the six phases included in 6E Instructional Model [7]. All these six phases, learning activity and habits of mind are shown in the sample of lesson plan.

Overall, this study aimed to point out the habits of mind that can be nurtured among students while doing their STEM project.

\section{METHODOLOGY}

This study was a fully qualitative case study which involved one intact class and conducted with observation, photo and video captures, interviews and students' documentation and analysis.

The samples were 30 Form One students in a sub urban National Primary School in Kelantan, whom have been exposed to the Secondary School Curriculum Standard (KSSM) syllabus. The participants were chosen because they could provide information-rich responses [8]. This current study was conducted after school.

\section{INSTRUMENTS}

\section{Science Learning Module STEM}

The module was designed based on Thinking Based Learning (TBL) and the 6E Instructional Model. The TBL components include the thinking skill, habits of mind and metacognitive, while the $6 \mathrm{E}$ Instructional Model comprised six phases; Engage, Exploration, Explain, Enrich, Engineer, and Evaluate. The outcome of this module is to create a model of a raft. The buoyancy and density which are related to a science concept have been infused into this module.

\section{Semi Structured Interview Protocol}

The semi structured focus group interview with the selected group was done after the fifth week to gauge the student habits of mind developed throughout the intervention. The examples of the questions were as follows: 
a) What makes you excited to take part in doing the project?

b) Why do you choose such materials in constructing your raft?

c) Why do you think sharing of idea is important?

The probing questions were asked to obtain deeper and detailed information, understanding of concept, idea, and thinking during the interview.

\section{Intervention: The Green STEM Project}

There were 30 participants comprised of 10 males and 20 females. All of them were divided into six small groups namely:

$\begin{array}{ll}\text { Group One } & : 5 \text { males } \\ \text { Group Two } & : 5 \text { males } \\ \text { Group Three } & : 5 \text { females } \\ \text { Group Four } & : 5 \text { females } \\ \text { Group Five } & : 5 \text { females } \\ \text { Group Six } & : 5 \text { females }\end{array}$

Each lesson plan was designed to be completed in two hours time. The learning process of each lesson plan followed the $6 \mathrm{E}$ Instructional Model. The summarized examples of the lesson plan adapting TBL for five weeks are presented in Table 1. This intervention consisted of six phases namely (1) Engage, (2) Explain, (3) Explore, (4) Engineering, (5) Enrich, and (6) Evaluate.

\section{Lesson Plan:}

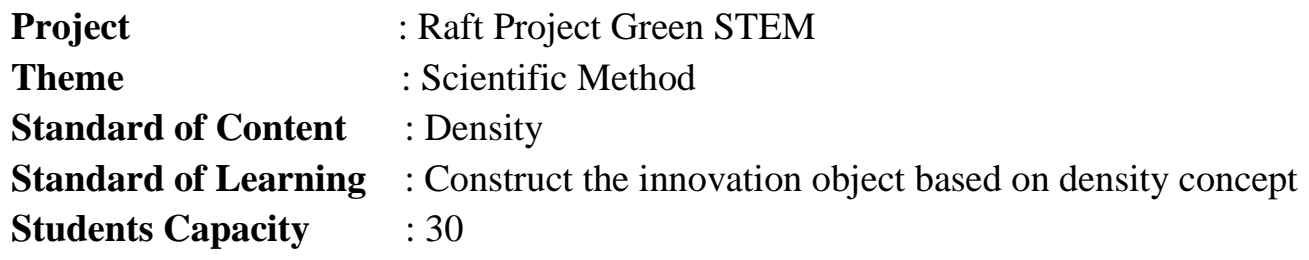

\section{Learning outcomes based on the project:}

i. Students understand the concept of energy transfer and change

ii. Students could apply the density concept in their project work

\section{Thinking Based Learning (TBL):}

i. Skilful thinking

Critical and creative thinking

ii. Metacognition

Question purposed concept

\section{iii. Habits of mind}

Listening with understanding and empathy

Questioning and problem posing

Thinking flexibly

Thinking independently

Creating, imagining and innovating

Applying past knowledge to novel situations

Thinking about your thinking 
Table 1 Lesson plan for Green STEM Raft Project

\begin{tabular}{|c|c|c|c|c|c|c|}
\hline Phase & $\begin{array}{l}\text { Standard of } \\
\text { learning }\end{array}$ & \multicolumn{3}{|c|}{$\begin{array}{l}\text { Teaching \& learning } \\
\text { activity }\end{array}$} & Habits of mind & TBL \\
\hline Engage & Density & 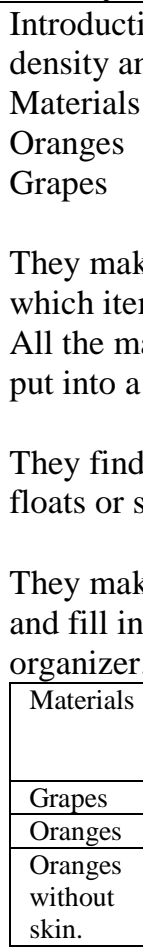 & $\begin{array}{l}\text { co } \\
\text { bu } \\
\text { iven } \\
\text { an } \\
\text { flo } \\
\text { eria } \\
\text { owl } \\
\text { ut } \\
\text { ks. }\end{array}$ & $\begin{array}{l}\text { ncept of } \\
\text { yancy. } \\
: \\
\text { nference } \\
\text { ts/sinks. } \\
\text { s given are } \\
\text { of water. } \\
\text { Jhich item } \\
\text { ervation } \\
\text { raphic } \\
\text { explanation }\end{array}$ & $\begin{array}{l}\text { Thinking flexibly } \\
\text { Gathering data from } \\
\text { observation. } \\
\text { Addressing the } \\
\text { problem from a new } \\
\text { angle. } \\
\text { They can develop } \\
\text { options and } \\
\text { alternatives. } \\
\text { They are able to } \\
\text { modify based on } \\
\text { additional information. } \\
\text { Habits of mind: } \\
\text { Listening with } \\
\text { understanding } \\
\text { and empathy. } \\
\text { Listening to the } \\
\text { essence of the person } \\
\text { speaking, listening to } \\
\text { what person is trying } \\
\text { to present. }\end{array}$ & $\begin{array}{l}\text { Thinking } \\
\text { skills } \\
\text { Creative } \\
\text { thinking } \\
\text { Students } \\
\text { will } \\
\text { generate } \\
\text { ideas and } \\
\text { solutions } \\
\text { with others } \\
\\
\text { Skilful } \\
\text { thinking: } \\
\text { Critical } \\
\text { thinking by } \\
\text { categorizing } \\
\text { the sinking } \\
\text { and floating } \\
\text { items by } \\
\text { observing. }\end{array}$ \\
\hline
\end{tabular}




\begin{tabular}{|c|c|c|c|c|}
\hline Phase & $\begin{array}{l}\text { Standard of } \\
\text { learning }\end{array}$ & $\begin{array}{l}\text { Teaching \& learning } \\
\text { activity }\end{array}$ & Habits of mind & TBL \\
\hline Explore & $\begin{array}{l}\text { Making a clay } \\
\text { boat. } \\
\text { With a clump of } \\
\text { clay given, } \\
\text { students need to } \\
\text { make clay boats } \\
\text { and ensure they } \\
\text { are able to float } \\
\text { Making a raft } \\
\text { Each group will } \\
\text { find out and } \\
\text { decide the } \\
\text { materials to be } \\
\text { used to build the } \\
\text { raft. } \\
\text { Students have an } \\
\text { opportunity to get } \\
\text { involve directly } \\
\text { with materials. } \\
\text { They work in } \\
\text { teams, build a set } \\
\text { of common } \\
\text { experiences that } \\
\text { prompt sharing } \\
\text { and } \\
\text { communication. }\end{array}$ & $\begin{array}{l}\text { Each group will be given a } \\
\text { clump of clay. } \\
\text { Questions: } \\
\text { (1)Why a clump of clay } \\
\text { sinks? } \\
\text { (2) What shape does this } \\
\text { clump need to make it } \\
\text { float? } \\
\text { They will build the clay } \\
\text { boat until it floats on } \\
\text { water. } \\
\text { Each group will be given a } \\
\text { chance to use any material } \\
\text { they prefer in making the } \\
\text { rafts. They have to } \\
\text { calculate the costs, know } \\
\text { how and where to get the } \\
\text { materials. Once again, they } \\
\text { will have a meeting to } \\
\text { decide their raft design. } \\
\text { They will present their raft } \\
\text { designs to other groups } \\
\text { and gain ideas by listening } \\
\text { to their comments. }\end{array}$ & $\begin{array}{l}\text { Habits of Mind: } \\
\text { (1)Questioning } \\
\text { and problem } \\
\text { solving. } \\
\text { Having a questioning } \\
\text { attitude and knowing } \\
\text { what data are needed. } \\
\text { They will be having } \\
\text { discussion among } \\
\text { themselves. } \\
\text { (2)Applying past } \\
\text { knowledge to } \\
\text { novel situations. } \\
\text { Use what they have } \\
\text { learned, assessing } \\
\text { prior knowledge; } \\
\text { transferring } \\
\text { knowledge beyond the } \\
\text { situation in which it } \\
\text { was learned. } \\
\text { (3)Listening with } \\
\text { understanding } \\
\text { and empathy. } \\
\text { Devoting mental } \\
\text { energy to another } \\
\text { person's thought and } \\
\text { ideas. } \\
\text { (4) Thinking } \\
\text { Independently. } \\
\text { They learn from } \\
\text { each other in } \\
\text { groups. }\end{array}$ & $\begin{array}{l}\text { Skilful } \\
\text { thinking: } \\
\text { Critical } \\
\text { thinking. } \\
\text { In making } \\
\text { clay boat } \\
\text { floating, } \\
\text { they should } \\
\text { use the } \\
\text { concept of } \\
\text { density and } \\
\text { buoyancy. }\end{array}$ \\
\hline
\end{tabular}




\begin{tabular}{|c|c|c|c|c|}
\hline Phase & $\begin{array}{l}\text { Standard of } \\
\text { learning }\end{array}$ & $\begin{array}{l}\text { Teaching and learning } \\
\text { activity }\end{array}$ & Habits of mind & TBL \\
\hline Explain & $\begin{array}{l}\text { Applies concepts, } \\
\text { principles and } \\
\text { theories related to } \\
\text { the system }\end{array}$ & $\begin{array}{l}\text { They use the concept of } \\
\text { density and buoyancy in } \\
\text { explaining to other groups. }\end{array}$ & $\begin{array}{l}\text { Habits of mind: } \\
\text { (1)Listening with } \\
\text { understanding } \\
\text { and empathy. } \\
\text { Devoting mental } \\
\text { energy to another } \\
\text { person thought and } \\
\text { ideas. } \\
\text { (2)Applying past } \\
\text { knowledge to } \\
\text { new situations. } \\
\text { Intelligent humans } \\
\text { learn from experience. }\end{array}$ & $\begin{array}{l}\text { Skilful } \\
\text { thinking: } \\
\text { Creative and critical } \\
\text { thinking. }\end{array}$ \\
\hline Engineering & $\begin{array}{l}\text { Density concept } \\
\text { Buoyancy concept }\end{array}$ & $\begin{array}{l}\text { Students construct the raft } \\
\text { models using the materials } \\
\text { they have chosen. } \\
\text { They sketch their raft } \\
\text { designs and then share } \\
\text { them with class members. }\end{array}$ & $\begin{array}{l}\text { Habits of mind: } \\
\text { (1)Applying past } \\
\text { knowledge to } \\
\text { new situations. } \\
\text { Intelligent humans } \\
\text { learn from } \\
\text { experiences. } \\
\text { Participants use their } \\
\text { experience when } \\
\text { constructing the clay } \\
\text { boats. They transfer } \\
\text { their experiences to } \\
\text { new situations in } \\
\text { constructing the raft } \\
\text { models but using } \\
\text { different materials. } \\
\text { (2) Creating, } \\
\text { imagining and } \\
\text { innovating. } \\
\text { Try in different way. } \\
\text { Generating new ideas, } \\
\text { using different } \\
\text { materials in } \\
\text { constructing the boats. }\end{array}$ & $\begin{array}{l}\text { Thinking skill: } \\
\text { Creative problem } \\
\text { solving, applying } \\
\text { technique from } \\
\text { theory, generating } \\
\text { ideas from others, } \\
\text { seeing engineering } \\
\text { as a team sport. }\end{array}$ \\
\hline Enrich & $\begin{array}{l}\text { Reconstructing } \\
\text { their rafts }\end{array}$ & $\begin{array}{l}\text { Students explore more } \\
\text { depth what they have } \\
\text { learned and transfer the } \\
\text { technology to their raft } \\
\text { project. } \\
\text { Some improvements are to } \\
\text { be made. }\end{array}$ & $\begin{array}{l}\text { Habits of mind: } \\
\text { Thinking flexibly } \\
\text { Looking at it in } \\
\text { another way, being } \\
\text { able to change } \\
\text { perspectives, } \\
\text { generating } \\
\text { alternatives. } \\
\text { Reconstruct and make } \\
\text { improvements to their } \\
\text { rafts. }\end{array}$ & $\begin{array}{l}\text { Metacognitive: } \\
\text { Students think about } \\
\text { their prototypes and } \\
\text { analyse them. }\end{array}$ \\
\hline Evaluate & $\begin{array}{l}\text { Writing reflective } \\
\text { journals }\end{array}$ & $\begin{array}{l}\text { Students discuss among } \\
\text { them on what they have } \\
\text { done and figure out } \\
\text { anything that has left out. }\end{array}$ & $\begin{array}{l}\text { Habits of mind } \\
\text { Thinking about } \\
\text { thinking } \\
\text { (metacognition). } \\
\text { Make reflections and } \\
\text { evaluate the quality of } \\
\text { their own thinking } \\
\text { skills and strategies. }\end{array}$ & $\begin{array}{l}\text { Metacognitive: } \\
\text { Students reflect back } \\
\text { what they have done } \\
\text { and write it in their } \\
\text { reflective journals. }\end{array}$ \\
\hline
\end{tabular}




\section{Data Collection}

The data were collected through observing students' participations during the intervention and also by conducting focus group interview after the fifth week. Student's individual behaviours and activities were taken in the classroom by taking field notes. Besides that, audio and visual data such as photographs, videos and voice recording were also collected.

During class observation, the students were observed for their habits of mind such as (1) listening with understanding and empathy, (2) questioning and problem posing, (3) creating, imagining and innovating, (4) applying past knowledge to novel situations, (5) thinking independently, (6) thinking flexibly and thinking about your thinking.

The focus group interview lasted for 30:34 minutes. They were asked for their opinions about the project. This interview was semi-structured and it involved general open-ended questions with a few sub-questions which are intended to elicit views and opinions from the participants. The interview had been video recorded and later transcribed.

\section{RESULTS AND DISCUSSION}

\section{a) Class Observation}

This project took approximately five weeks to complete. The activity of building bamboo raft was done in six phases, in which it started with the engagement phase and followed by the remaining phases, as discussed in the following section.

\section{Engage Phase:}

During the engage phase, all groups tried to find out the sinking and floating materials. They were given oranges, grapes, ice cubes and a bowl of water. Before putting each given item into a bowl of water, they were asked to predict which item would float or sink. After that, they discussed the answers derived from their observations. They compared the answers from observations and the predicted ones. All groups did the same activity.

\section{Explore Phase:}

In the explore phase, each group was given a clump of clay. The groups shaped it to make clay boats. Group One successfully shaped the clay boat and made it float on water. The other groups' members came to observe how they had made it happened. They have learnt to think independently by learning from each other in same condition.

\section{Explain Phase:}

Once they got the results from their observations, they discussed within group before two members from each group presenting and explaining the outcomes in front of the class. The other students listened with understanding and empathy, meanwhile some of them tried to compare their answers with the presenters. 


\section{Engineering phase:}

In this phase, students needed to sketch their decided raft designs onto mah-jong papers and shared them with their friends. Besides that, they also decided on what materials to be used. Students used their previous experiences when making clay boats. They brought their past knowledge to new situations that enabled them to create new ideas by using different kinds of materials in constructing their rafts. All groups did the same thing; constructed their rafts by referring to the sketches drawn and materials chosen.

\section{Enrich phase:}

During this phase, students discussed among their friends and the teacher with regard to the improvement they should make. They were advised to look at their outcomes in another way, thus they generated other perspective. Group One decided to put more polystyrene under the raft so that it can be higher from water level. Group Two decided to put a cork under the raft to achieve the same result. Meanwhile, Group Three decided to put sail on their raft model. Group Four on the other hand decided to put turbine with batteries to make the raft moving faster. The other two groups were satisfied with their current raft models.

\section{Evaluate phase:}

In this phase, the level of learning and understanding processes that had taken place were determined by both the students and the teacher. This phase involved thinking about their thinking or also known as metacognition. Students made a reflection on what they had done and wrote it in their reflective journals. This activity applied to all groups.

\section{b) Focus Group Interview.}

One out of six groups was chosen as a target group for an interview. Group One that was chosen consisted of five male students. The selection was made because the group members showed interest and good collaboration among each other. All groups showed the collaborative attitudes among themselves, but Group One worked more actively and collaboratively during the project period. The classroom was set up where desks were positioned in rows and students were facing one another which resulted in the students' frequent collaboration. However, sometimes it was difficult for students to pay attention since they had to turn around to face the board. The researcher also noticed that students came forward as they could not see the teacher who was standing in front. Students were asked a series of questions such as their opinions on their project activity they had have received.

\footnotetext{
Researcher :"What makes you motivated to take part in the project activity?"

Student 1 : "Actually we have learned something new, we can make it ourselves, make it real thing".
}

This implied that he was engaged with the lesson and he loved to do exploration. He was using thinking flexibility, where he developed option and alternatives by saying "we can make it ourselves and make it real".

In addition to the interview, student 1 added: "If we help each other, I think it will not be so difficult. Besides, everyone here gets involved and helps each other, we also learned from each other". This statement implied about collaborative work and thinking independently. 


\section{Researcher}

The students said
: "What is the benefit of the presentation, since you have to present the raft sketch before starting the project?"

This implied about sharing idea and communication skill. This also has open space for students to deliver questions and solve problem when something needed to be clear. During the presentation, the students were nurtured to listen and understand with empathy.

Researcher : "Ok back to your project. Before teacher gives you this task, you have done simple experiment in engage phase where you have to find out the items given whether floating or sinking. Can you mention what items they gave to you?"

Student 2 :"Ooooo..........they gave us oranges, grapes and ice cubes. We found out that oranges and ice cubes floating, whereas grapes sinking."

Researcher : "Oranges are bigger as compared to grapes, why grapes sinking?"

Student 3 : "Mmmmm.....because oranges got the air sacs."

Researcher : "What makes you said that?"

Student $4 \quad$ :"When we peel off their skin, they sinking. This showed that air sacs on their skin make them floating."

These conversations showed that the students applied flexibility thinking in their task. They tried to address the problem from a new angle. When people tried to address their problems from new angle using a novel approach, which [9] referred to as "lateral thinking", their minds were open to change based on additional information, new data or even reasoning that contradicted their beliefs.

Researcher :"Oooo good...., you can see the path now...mmm during the exploration phase you have been challenged by your teacher to make a clay boat. How you manage it? Since when you put a clump of clay into the water, it sinks."

Student 5 :"At first, we think this might be crazy....how we going to make the boat from clumps of clay that is sinking....but teacher gives a few examples of floating things, such as ship...they are heavy and big...how they can floating? So we try to make the shape that can make it floating....we shape the clay..when we shape it like a boat, a deeper space at the middle... and make sure no hole at bottom of the boat...we put slowly into the water....and ....it float!"

Researcher : "So what makes them float you think? Its shape or..?"

Student 5 : "The air space...like oranges...air sacs...the air space on the middle of the boat..." 
Researcher : “...Mmm so what you can say about that?"

Student 5 : "They are actually related to density and buoyancy...that's why heavy ship can float too."

This conversation showed that, the students applied past knowledge to new situations. They used their knowledge about the shape of ship and applied it to their task of making clay boats. One of the distinguishing characteristics of humans is our inclination and ability to find problems to solve. Effective problem solvers know how to ask questions to fill the gaps between what they know and what they do not know [6].

Researcher : "Mmmm....during the engineering phase, you were asked to sketch your raft before you work on it and you have been given any choice of materials you want to use. Can you show me your drawing sketch?"

Students brought their sketch and showed it to the researcher.

Researcher : "What material you choose?"

Students : "We choose pop sickle and polystyrene."

Researcher : "Why you put polystyrene under the pop sickle stick? Do the pop sickle going to sinking without polystyrene?"

Students : "Nope". "We have tried without polystyrene, they still can float, but the water level is too near to them, so we put polystyrene under it to make it higher than water level."

These implied that how the students created, imagined and innovated in solving their problems. All human beings have the capacity to generate novel, clever or ingenious products, solutions and techniques- if the capacity is developed [6]. Creative human beings try to conceive solutions to problems differently, examining alternative possibilities from many angles.

As mention earlier, the habits of mind is a part of thinking based learning. The factor that contribute to student's thinking skills. Accuracy, seeking clarity, restraining impulsivity, taking position when necessary and being sensitive to the needs of others are the developed characters that relative to the habits of mind. Whereas five dimensions model of learning which are named correspondingly (1) towards positive attitudes learning, (2) acquisition and integration of knowledge, (3) extending and refining knowledge, (4) meaningfully using knowledge, and (5) productive habits of mind are five dimensions model of learning in habits of mind. In productive habits of mind, students are encouraged to develop those mental habits which will enable them to become life-long learners [5]. In this current study, there were seven habits of mind found; (1) questioning and problem solving, (2) listening with understanding and empathy, (3) thinking about your thinking, (4) thinking flexibility, (5) applying past knowledge to real situations, (6) creating, imagining and innovating, and (7) thinking independently. While doing STEM project in the explore phase, they were given clump of clay, they need to think in how to make it floating. These how they requested to questioning and solving the problem. While the other group is presenting their out-come, students requested to listening with understanding and empathy.

During the evaluation phase, students are required to write the reflective journal to what they have done before, they need to think and rethink back what they have done. Students also have been encouraged to accept others view for improvement. With their experience in making their clay boat 
float, they can shifted this concept to their solar raft, their STEM Project. However they have been encouraged to try in different way such use the different materials, and looks what differences occur. Letting them become innovating and creating. Referring to Figure 1.0, it shows that habits of mind serve as the warp for the curriculum. In lessons plan, teachers basically think about instructional methodologies, assessment strategies and they hold on their minds a level of outcomes. Figure 1 also summarizes the outcomes suggested for teachers in writing their lesson plans.

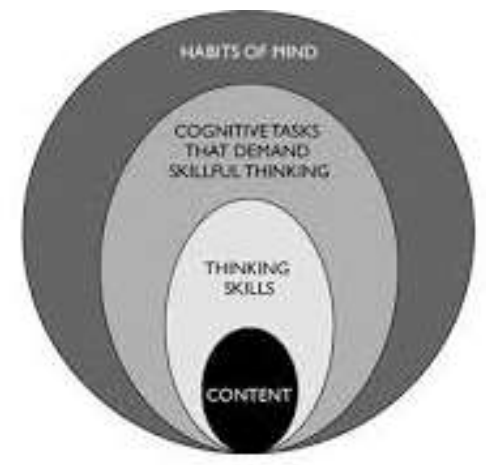

Figure 1. Four levels of educational outcomes Sources: (Costa \& Kallick, 2009)

\section{CONCLUSIONS}

However, the habits of mind depend on the classroom environment, good learning environment, whereby the teachers are responsible for providing the students with good learning environment and developing the productive habits of mind. In other words, developing the productive habits of mind depends on the teachers and their awareness and knowledge. In nurturing habits of mind among students, teachers need to plan teaching that suit the habits of mind product development. In general, this requires a set of teaching activities and procedures that must be implemented in the classroom. Students need to be engaged in appropriate activities because the benefit of actively engaging students in the construction of science knowledge can provide them with an opportunity to engage in habitual thinking like scientists. Therefore, in preparing students for a life-long learning, they need to have skills to behave intelligently when they are faced with problems for which the answers are not immediately known.

\section{REFERENCES}

[1] Armstrong, J. M. A. (1950). Projects and their place in education. London: Sir Issac Pitman \& Sons, Ltd.

[2] Swartz, R., \& Reagan, R. (1998). Infusing critical and creative thinking into content instruction. The National Center for Teaching Thinking. Washington.

[3] Costa, A., \& Kallick, B. (2000). Discovering \& exploring habits of mind. Association for supervision \& curriculum development. Alexandaria: VA:ASCD.

[4] Alhamlan, S., Aljasser, H., Almajed, A., Almansour, H., \& Alahmad, N. (2018). A systematic review : Using habits of mind to improve student's thinking in class. Higher Education Studies, 8(1), 25-35.

[5] Elyousit, Y. A. K., \& Abdelhamied, N. E. (2013). Assessing secondary school teachers' performance in developing habits of mind for the students. International Interdisciplinary Journal Of Education, 2(2), 168180. 
[6] Costa, A., \& Kallick, B. (2009). Learning and leading with habits of mind: 16 characteristics for success. Alexandria: Association for Supervision and Curiculum Development.

[7] Burke, B. (2014). The ITEEA 6E learning by DesignTM model: Maximizing informed design and inquiry in the integrative STEM classroom. Technology \& Engineering Teacher, 73(6), 14-19.

[8] Patton, M. Q. (1990). Qualitative evaluation and research methods. Newbury, Park: CA: Sage.

[9] de Bono, F. (1991). The CoRT thinking program. In A.Costa (Ed.), Developing minds: Program for teaching thinking (Vol. 2, pp. 27-32). Alexandaria: VA:ASCD. 